finds, such as at Pithekoussai on Ischia and Lefkandi on Euboia. His own excavational work concentrated on Kythera, where with George Huxley he pioneered research on the connections between Crete and the mainland in the Bronze Age), and his beloved Knossos, a rich site long after Minos; all of this he saw to publication, as well as much dug by others at Knossos. The core to his work, that for which he is rightly lauded throughout the archaeological community, was his study of the pottery of the earlier first millennium BC; his Greek Geometric Pottery (1977) is only surpassed by the second edition, published posthumously; his students and admirers plan a further supplementary volume on the topic. The broader view was not neglected: in 2003 he published a second edition of Geometric Greece (2003), where he tackled the history of the period, perforce dependent largely on archaeological evidence, with a clarity and freedom from jargon which was always a hallmark of his approach.

The excavations at Knossos were conducted under the aegis of the British School at Athens, which he served as MacMillan Student, Editor of the Annual, Chairman of the Managing Committee and then Vice-President. He was about to set off to a colloquium in his honour in Athens (involving many of his pupils) when he died; it became a fitting, and academically impressive, memorial meeting.

\section{Late Geometric Attic tankard in the Institute collection first published by Nicolas Coldstream in his "Greek Geometric Pottery"}

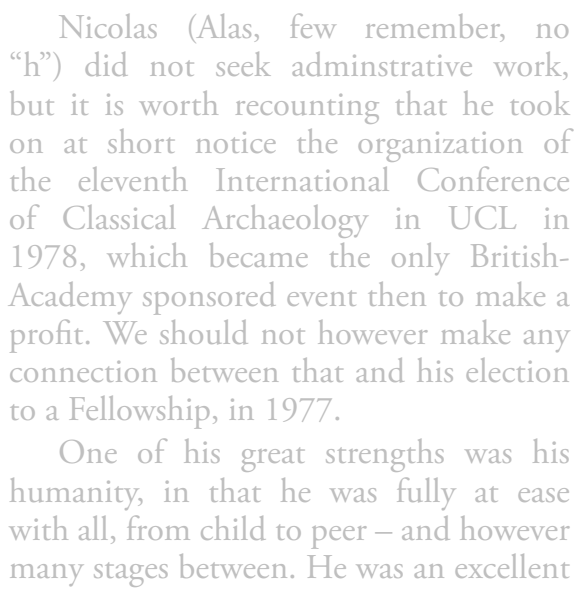

smoother of ruffled feathers, such as when chairing a session in a conference in the BM he was able to snatch a break during a heated argument between two Italian colleagues on a relatively obscure Etruscan matter to announce that there did not appear to be a consensus emerging and that it was time for lunch. He has attempted a similar feat in several more recent articles on the thorny issue of the contribution of Greek pottery to the dating of sites in the Holy Land. A point which he continually made in print and conversation was that in this difficult area of dating in protohistory it is not the individual object that decides the issue but the collective "voice" of the whole corpus of indicative material.

There is an ongoing Nachlass, involving the second edition of GGP, as it is known to all in the trade, and, to bring the wheel full circle, the full publication of the pottery of "his" period in the British Museum. We will see there one of the many artistic talents of his wife, Nicola, whose drawings have always supplemented his texts.

John Nicolas Coldstream, archaeologist, born 30th March 1927, died 21st March 2008.

DOI: http://dx.doi.org/10.5334/ai.1105

\title{
The Peter Ucko Archaeological Trust
}

The Peter Ucko Archaeological Trust (Charity Commission no.1127398) has been set up in memory of Peter Ucko, formerly Director of the Institute of Archaeology and founder of the World Archaeological Congress. The objects of the Trust are to promote the exchange of information resulting from archaeological research; provide financial assistance (to indigenous and economically disadvantaged people) for education and training in archaeology, heritage management, and associated disciplines, and support any activity addressing inequalities and cultural conflict in the context of archaeological heritage and cultural property. The Trust will endeavour to promote respect for human rights by individuals and organizations and to protect the rights of indigenous people over their cultural property, including ancestral human remains.

For as long as WAC continues to uphold the values that Peter believed to be integral to it, the intention (in the first instance) is to provide financial support to indigenous and economically disadvantaged people to facilitate their participation in international meetings of WAC. The Trust was set up with $£ 50,000$ from Peter's estate, but it is hoped that this sum will be added to, and thus enable the Trust to expand its activities.

The Trust welcomes donations, however small or large. Donations may be sent to Barbara Brown, Institute of Archaeology, 31-34, Gordon Square, London WC1H 0PY.

Donations can be sent immediately to the above address (for the attention of Mary Carey). If you would prefer to wait until the Charity Registration Number is received, donations may be made by way of pledges. Donors will be notified when the Charity Registration Number is available and the pledges redeemed. Donations can be made by cheque, or by bank transfer to the William Sturges \& Co Client account, National Westminster Bank, Sort code: 56-00-33, Account number: 48327042 (Ref: Peter Ucko Archaeological Trust).

Trustees: Jane Hubert, Professor Peter Stone, Dr Siân Jones, Professor Stephen Shennan, Professor Sir Robert Boyd. 